\title{
O livro-mundo. Milton Hatoum e a literatura do presente
}

\section{Susana Scramim}

Resumo: Este ensaio parte da premissa de que a obra de Milton $\mathrm{Ha}$ toum enfrenta os impasses da modernidade literária, impasses esses que decorrem de um sentimento de esgotamento e cansaço já experímentados pela literatura dita moderna no ato mesmo de sua instituição, isto é, na cultura decadente do final do século xıx. A questão proposta é que a experiència do esgotamento é a experiència mesma da literatura e, por isso, nào estaria restrita à modernidade. No entanto. é a literatura moderna que produzirá o discurso do mal-estar diante desse esgotamento.Palavras-chave: Milton Hatoum, teoria da modernidade, literatura comparada.

Abstract: This essay starts from the premise that the work of Milton $\mathrm{Ha}$ toum faces the impasses of the literary modernity, impasses which result from a wearing out and weariness fecling already cxperienced by the socalled modern literature in the very act of ifs institution, that is, in the decaying culture of the end of the xix century. The proposed question is that the wearing out experience is the experience of literature itself and, therefore, wouldn't be restricted to modemity. However, it's the modern literature which brings forth the discourse of malaise towards this wcaring out. Keywords: Milton Hatoum, theory of modenity. comparative literature. 
Ut nihil non iisdem verbis redderetur auditum.

Gaius Plinius Secundus

Desde o seu primeiro livro, de 1979, Amazonas: palavras e imagens de um rio entre ruinas, ${ }^{1}$ o trabalho de Milton Hatoum vem-se desenhando por entre as imagens de ruínas. Os poemas e relatos publicados ao longo de trinta anos não fazem senão atestar seu compromisso com a história, uma história que compreende, com base nos estudos sobre as imagens da história e da literatura de Walter Benjamin, o processo de "vir a ser e declinar" como inerente a si. Nesse sentido, as ruínas são encaradas como material com o qual se faz o presente, abdicando-se com isso da relação de causalidade entre atual e inatual, memória e realidade imediata. Longe de promulgar a decadência, as ruínas passam a ter função construtiva, passam a ser um método de tratar com o excesso da modernidade, o excesso de memória que caracteriza todas as nossas sociedades fundadas na cultura do Ocidente. $O$ trabalho com as ruínas, imagens da história, é a maneira pela qual a memória recebe tratamento formal na obra de Milton Hatoum. Há um eixo em torno do qual giram tanto o livro de poemas Amazonas... (1979), quanto as narrativas Relato de um certo Oriente (1989), Dois irmãos (200o) e Cinzas do Norte (2005). Estas têm como narradores seres saturados de memória, os quais desejam contá-las, fazer com que voltem à vida dos vivos. No entanto, para tal dispõem apenas de ruínas, material destruído pelo processo vital de "vir a ser e declinar", que é o movimento da história, da história que faz tudo estar presente mediante esse processo, pois nas ruínas o passado se torna presente, isto é, o passado torna-se dinâmico. Para Aristóteles, ${ }^{2}$ e na leitura que Giorgio Agamben faz dele, "dynamis" é a potência passiva das coisas, a força que não se materializa num ato ou numa coisa, mas está ali. Recordar e transpor informações de um tempo para outro, produzindo, assim, sentidos para esse outro tempo, é capacidade de transformar o passado em presente sem com isso repetir o passado. Paolo Virno, em Il ricordo del presente: saggio sul tempo storico, chamou essa força também de "dynamis", ou seja, a força que permite lembrar.

1 HATOUM, Milton. Amazonas: palavras e imagens de um rio entre ruínas. São Paulo: Livraria Diadorim, 1979. A revista Babel, em seu primeiro número, republicou vários poemas desse livro de Hatoum. Cf. Babel, Santos, V. 1, n. 1, mar./jul. 2000.

2 ARISTÓTELES. De anima. Apud AGAMBEN, Giorgio. A potência do pensamento. Trad. Carolina Torquato. Revista do Departamento de Psicologia, UFF, Niterói, v. 18, n. 1, jan./jun. 2006. 
O trabalho desenvolvido por Milton Hatoum se insere, com sua disposição em transformar as suas obras em imagens históricas, num complexo âmbito artístico cujo objetivo e resultado se alcançam na percepção do quanto a arte está imersa num processo histórico vital. Mediante esse procedimento, há uma recusa, por parte da obra, em criar mundos paralelos, autônomos e acabados em si mesmos. Nesse complexo âmbito de produção de arte, a consciência do declínio e da decadência é parte constitutiva da noção de tempo histórico. Por isso, não há mais o interesse por noções como as de passado ou futuro, pois estão todos imersos num catártico tempo presente. Para Walter Benjamin a "pré" e a "pós-história" da obra se cumprem em seu presente. $\mathrm{O}$ filósofo alemão encontrou esse complexo âmbito artístico já nas obras do drama barroco alemão. ${ }^{3} \mathrm{E}$ detecta no pensamento germânico que produz o drama do século xvir elementos que serão desdobrados na sua pós-história: o expressionismo. Benjamin explica que a concepção de história do século xvir é "panoramática", pois determinada pela justaposição de todos os objetos memoráveis. $\hat{E}$ a vivência do tempo que tudo destrói, do caráter implacavelmente efêmero de todas as coisas, que gera o gosto acentuado pelo pitoresco, pela paisagem natural como espaço de refúgio do mundo.

\section{O norte como Oriente}

Já no primeiro poema do livro de Milton Hatoum, Amazonas: palavras e imagens de um rio entre ruinas, é possivel encontrar a potência que permite lembrar. $\mathrm{O}$ poema "Rio entre ruínas" recorda e desdobra os sentidos de um ensaio de Euclides da Cunha intitulado "Entre as ruínas",

No poema "Rio entre ruínas" de Milton Hatoum, a história do rio se entrelaça com a da região. O processo de declínio dá o tom a essa história. Os verbos que compõem os versos da primeira estrofe perguntam pelas ruínas, pelas sobras do rio e da região:

Que sobrou de ti?

Que outra folha brotar?

Que rugido ainda escoar?

3 Cf. BENJAMIN, Walter. Origem do drama barroco alemão. Trad. Sergio Rouanet. São Paulo: Brasiliense, 1984.

4 CUNHA, Euclides da. Contrastes e confrontos. Obra completa. Rio de Janeiro: Nova Aguilar, 1995. v. I.

220. SCRAMIM, Susana. O livro-mundo. Milton Hatoum e a literatura do presente 
Qual o verbo manhoso escorrer?

Rosnar? remar? roçar? sussurrar

Qual verde?s

"Sobrar", "brotar" são ações passivas e, por sua vez, "escoar", "escorrer", "rosnar", "roçar", "sussurrar" indicam ações mínimas insinuando quase não ações. A história do rio e da região é resultado delas, as não ações ou ações mínimas, e não de um sujeito produtor das ações ativas, a "energeia" aristotélica, ${ }^{6}$ a passagem à ação prática. Em entrevista recente, Hatoum falava de certa marca muito forte que a floresta imprime em quem já viveu nela, uma espécie de passividade diante do infinito, isto é, diante do sublime. Essa marca, segundo o autor, faz com que se enxergue "o verdadeiro tamanho do ser humano"? O rio e a região no poema podem ser o Amazonas, como também qualquer rio. O que importa é o fluxo devastador do rio que produz sobras. Suas margens arruinadas são matéria. E é dessas ruínas que brota o poema, um sussurro. Diante da ruína o poeta se vê motivado a escrever, e sua escrita se faz fluxo novamente, produzindo mais "ruinamentos", mais terras caídas.

Planície e país finalmente se entrelaçam

não em gravetos ou essência.

Se entrelaçam em farpas de gaiola

como um pássaro que ao voar desaba

e cai no desconhecido

cai sobre o mais disforme

sobre a matéria que não é mais única

que não é plana ou funda

que não é rio ou relva

que já pode ser tudo:

Maranhão, degelo, Ucrânia. ${ }^{8}$

5 HATOUM, Milton. Amazonas: palavras e imagens de um rio entre ruínas. São Paulo: Livraria Diadorim, 1979, p. 3.

6 Conferir no estudo de Giorgio Agamben anteriormente citado a distinçāo que Aristóteles faz entre "dynamis" e "energeia", respectivamente, ação em potência, que não se põe em prática, potência passiva, e a "energeia", potência ativa, a ação prática propriamente dita.

7 "Milton Hatoum, ou o Flaubert da Floresta," entrevista concedida a Rogério Galindo, da Gazeta do Povo, Curitiba, 22 out. 2006, p. 8. Caderno G.

8 HATOUM, Milton. Amazonas: palavras e imagens de um rio entre ruínas, op. cit., p. 3. 
Terras caídas e fluxo informe são os movimentos que Euclides da Cunha observou e anotou em sua viagem ao Amazonas. Os ensaios de Euclides da Cunha que derivaram dessa viagem destacam a existência de um mundo em decadência, separado, mas nem tanto, do país, um mundo perdido que causa estranheza a qual, paradoxalmente, produz certa identificação, certa familiaridade no espírito nacionalista daquele produtor da visão da Amazônia. Nas "Impressões gerais" de outro livro de Euclides da Cunha sobre a Amazônia, À margem da história, destaca o contrassenso provocado pela decadência natural da história da região.

Naqueles lugares, o brasileiro salta: é estrangeiro, e está pisando terras brasileiras. Antolha-se-lhe em contrassenso pasmoso: à fiç̧ão de direito estabelecendo por vezes a exterritorialidade, que é a pátria sem a terra, contrapõe-se uma outra, rudemente física: a terra sem a pátria.

Numa só noite (29 de julho de 1866) as "terras caídas" da margem esquerda do Amazonas desmoronaram numa linha contínua de cinquenta léguas.

É o processo antigo, invariável - patenteando-se ainda no diminuto raio da nossa história. 9

Ele separa a Amazônia do Brasil para vê-la melhor, para dissecá-la e devolvê-la, não mais como território político nacional, mas permeada de uma visão exterritorial, geográfica, a qual inclui a nação, porque carregada de impressões humanas. $O$ texto de Euclides da Cunha se constrói a partir de contrastes; no entanto, os confrontos construídos obedecem, de alguma maneira, a uma estrutura de espelho: pátria sem terra; terra sem pátria.

Os diversos tempo e espaço do mundo amazônico são pensados de maneira simultânea dentro e fora das fronteiras territoriais e históricas. O pensamento de Euclides da Cunha toma parte dessas obras em que o desejo de ser arte importa mais do que o fazer artístico propriamente dito. Ruínas desse comportamento frente à arte farão parte também do arquivo ao qual recorreu a antropofagia cultural da vanguarda modernista. Em "Nativismo provisório", Euclides da Cunha sublinha: "Deste modo, a simpatia pelo estrangeiro, baseamo-la, até movidos pelo egoísmo, nos nossos interesses imediatos e mais urgentes" 10

9 CUNHA, Euclides da. À margem da história. 3. ed. Porto: Chardon, 1922, p. $14-16$.

10 Idem. Contrastes e confrontos. Obra completa, op. cit., p. 212.

222. SCRAMIM, Susana. O livro-mundo. Milton Hatoum e a literatura do presente 
No entanto, na vanguarda modernista o irracionalismo toma o lugar do ponto de vista sóbrio e racional com o qual Euclides da Cunha vê o processo de "declínio" e "vir a ser" da Amazônia e do país. No livro À margem da história, o ensaísta assinala que na Amazônia o imaginário popular substitui o aforismo utilizado para expressar os desmandos da época colonial: ultra aequiotialem non peccavi. A ilha de Marapatá, situada à entrada de Manaus, no rio Negro, tem a função de depositário da consciência do recém-chegado, passando a ser chamada de 'ilha da Consciência'. Ao relatar essa pequena parte do imaginário local, Euclides da Cunha se espanta com o alcance desse "prodígio da fantasia popular" provavelmente se referindo à relação existente entre o "abdicar das qualidades nativas" antes de entrar em Manaus e o caráter dos brasileiros que também abdicam de qualidades na vida em sociedade." A decadência que é a história do país espelhada na da região amazônica, "à exterritorialidade, que é a pátria sem a terra, contrapõe-se uma outra, rudemente física: a terra sem a pátria", ${ }^{12}$ reaparece em Macunaíma quando o herói deixa a consciência na ilha de Marapatá. Ao retornar ao Uraricoera, Macunaíma "se desculpou, subiu na montaria e deu uma chegadinha até a boca do rio Negro pra buscar a consciência deixada na ilha de Marapatá. Jacaré achou? nem ele. Então o herói pegou a consciência dum hispano-americano, botou na cabeça e se deu bem da mesma forma". ${ }^{13}$

Em "História com data", de 1921, Mário de Andrade já abordara o problema da troca de consciência. O leitor tem diante de si a história de um operário que recebe por transplante o cérebro de um aviador. É a modernidade tentando entrar num corpo rústico e despreparado para receber toda aquela quantidade de informações novas, tecnológicas e efêmeras. $\mathrm{O}$ forte corpo do operário se distingue visivelmente do corpo frágil do aviador, que naquelas condições trágicas do acidente está inutilizado. A arte moderna, aérea, etérea, parceira da técnica, distingue-se, mas terá que conviver com a arte do passado, robusta, séria e veículo de valores eternos. Raúl Antelo, em "Macunaíma e a ficção de fronteira", antevê nessa pós-história machadiana, agora com data, uma "sorte de prototexto macunaímico" e quando Mário

\footnotetext{
11 Idem. À margem da história, op. cit., p. 22.

12 Idem, p. 14.

13 ANDRADE, Mário de. Macunaima: o herói sem nenhum caráter. Ed. crítica. Telê Porto Ancona Lopes (coord.). Paris: Association Archives de la Littérature latino-américane, des Caraïbes et africaine du XXe siècle; Brasilia: CNPq, 1988, p. 148.
} 
de Andrade a escreve "está de fato ensaiando um autômato que discute a arte aere perenius herdada dos mestres do passado"."14

\section{A vanguarda no meio do caminho}

A vanguarda por seus arroubos iconoclastas e por seu antirracionalismo fará sobreviver o pensamento filosófico de Nietzsche; e por suas experiências com o método de depuração dos afetos e do inconsciente na expressão artística oferece reflexões que a interconectam com a psicanálise moderna. Essa interconexão com a psicanálise é apresentada por Mário de Andrade mediante outra conexão: a do pensamento do psiquiatra socialista argentino José Ingenieros. Mário de Andrade em $A$ escrava que não é Isaura: discurso sobre algumas tendências da poesia modernista, escrito entre abril e maio de 1922, mas publicado somente em 1925, ressalta "a NECESSIDADE DE EXPRESSAR a sensação recebida por meio do gesto. (Falo gesto no sentido empregado por Ingenieros: gritos, sons musicais, sons articulados, contrações faciais e o gesto propriamente dito.)" ${ }^{15}$ Mário de Andrade, na mesma obra, ainda destaca aquilo que analisa como a marca de seu tempo presente e que, pare ele, é também o traço da modernidade: o excesso de memória, a "arte robusta" e eterna, e a fadiga que isso produz na vida cultural obrigada a repetir os preceitos e fórmulas já experimentados e acertados.

14 Raúl Antelo ainda nesse mesmo ensaio chama a atenção para o fato de que o acidente aéreo que cuímina na morte cerebral do aviador é uma alegoria aérea de um declínio duplo, "cuja queda se interpreta tanto como anulação do desejo de ultrapassar a lei e o limite quanto de efetiva realização dessa pulsão integradora e catastrófica com a terra natal e a língua materna." CF. ANTELO, Raúl. Macunaíma e a ficção de fronteira. Arca, Revista Literária Anual. Porto Alegre: Paraula, n. 1, p. 25, 1993.

15 ANDRADE, Mário de. "A escrava que não era Isaura“. In: Obra imatura. Belo Horizonte: Itatiaia, 1980, p. 203. No seu estudo sobre as relaçōes entre a vanguarda brasileira e a hispano-americana, Raúl Antelo observa que "apesar das contradições, existe um vínculo entre a combatividade e as pesquisas do psiquiatra [José Ingenieros] socialista e as experiências de ruptura no discurso poético dos escritores de São Paulo." Antelo nos relata que o psiquiatra socialista argentino participa da fundação do Partido Socialista Operário Internacional, em 1896. No entanto, irá abandonar as fontes primitivas socialistas para investir na sua pesquisa profissional como psiquiatra. Sua passagem da teoria econômica da história aos domínios do evolucionismo biológico e social não se deu sem a afirmação do culto pela individualidade vigorosa e sem compromissos, tomados de sua leitura de Nietzsche. Já antes da década de 1920, quando publica seus livros As forças morais: à juventude da América Latina e O homem mediocre, Ingenieros era leitura corrente entre os intelectuais argentinos, tanto na capital quanto nas províncias. Cf. ANTELO, Raúl. Na ilha de Marapatá. (Mário de Andrade lê os hispano-americanos). São Paulo, Brasília: Hucitec, Ministério da Cultura: Instituto Nacional do Livro, p. 3-4, 1986.

224 SCRAMIM, Susana. O livro-mundo. Milton Hatoum e a literatura do presente 
O homem instruído moderno, e afirmo que o poeta de hoje é instruído, lido com letras e raciocínio desde um país da infância em que antigamente a criança ainda não ficara pasmada siquer ante a glória da natureza. Um menino de 15 anos neste maio de 1922 já é um cansado intelectual.

Ela (a atenção) é uma das condições indispensáveis para que se dê a fadiga intelectual.

O raciocínio, agora que desde a meninice nos empanturram de veracidades catalogadas, cansa-nos, CANSA-NOS. ${ }^{16}$

Mário de Andrade sobrepõe a ideia de criação à de cópia de modelos e à de observância dos meios de expressão poética transmitidos pela tradição. Contra a fadiga intelectual ele toma de Vicente Huidobro, a quem lê nos artigos da revista L'Esprit Nouveau ${ }^{17}$, a teoria do poeta como verdadeiro criador do texto literário, criação na qual atuam a deformação e a síntese, aliás, dois modos de proceder da arte barroca. Em 1920, Vicente Huidobro publica em L'Esprit Nouveau um ensaio que funcionou como um tipo de manifesto que ratifica os princípios do Creacionismo. Em "A criação pura. (Ensaio de Estética)" desenvolve a teoria de que há um movimento circular na história da arte em cujo percurso se inclui um momento de decadência no qual os artistas "aprendem esta arte por receitas, habituam-se a ela e são capazes de praticá-la de memória [...]"18 Jorge Luis Borges, por sua vez, não creditava à palavra espontânea, pertencente ao uso cotidiano, e tampouco à busca pela síntese e exatidão do poema, o valor de substituto da repetição da tradição. No manifesto vanguardista do "Ultraísmo", publicado na revista Nosotros, em 1921, Borges assinala que o medo legítimo e justificado da retórica impele os, assim chamados, adeptos ao sencillismo a uma "outra classe de retórica envergonhada, tão postiça e deliberada quanto a geringonça acadêmica ou o palavrório lunfardo que se esparrama por qualquer obra nacional para criar o ambiente."19 A poesia dos "ultraístas" volta-se, de acordo com Borges, para o seu elemento primordial, a metáfora, "com independência máxima, que vai além das brincadeirinhas daqueles que comparam entre si coisas de forma semelhante.... ${ }^{20}$ A relação com o peso

\footnotetext{
16 ANDRADE, Mário de. A escrava que não era Isaura. Obra imatura, op. cit., p. 251.

17 Mário de Andrade era assíduo leitor de L'Esprit Nouveau e lê os artigos que Vicente Huidobro publica nessa revista francesa. Ver GREMBECKI, Maria Helena. Mário de Andrade e L'Esprit Noveau. São Paulo: IEB-USP, 1969; e ANTELO, Raúl. Desvairismo e criação pura. In: Na llha de Marapatá, op. cit. 
paralisante da memória tem em Borges uma conotação um pouco diferente da atitude iconoclasta das vanguardas. Em 1942, no conto "Funes el memorioso", o narrador de Borges, possuído por certa obsessão, tenta, passados, então, cinquenta anos do fato, com sua narrativa reproduzir com veracidade as coisas que Funes lhe contara naquela noite. Adverte-nos o narrador que sua narrativa não tem outro motivo senão reconstruir a memória de um diálogo entre Funes e ele, pois as palavras de Funes lhe são, naquele momento, irrecuperáveis, já que a máxima de Plínio sobre a Memória, “ut nihil non iisdem verbis redderetur auditum", "assim que repete exatamente toda a palavra ouvida”, não faz parte dos exercícios da prática de escrita do narrador. Diferentemente do personagem que ele tanto admira, o narrador não consegue reproduzir as palavras de Funes, não adota o estilo indireto por entendê-lo "distante e fraco; sei que sacrifico a eficácia desse relato; que meus leitores imaginem os entrecortados instantes que aquela noite me oprimiram". ${ }^{21}$ Irineu Funes, além de perceber todos os rebentos e cachos de uma parreira, lembrava-se deles em detalhes, "essas lembranças não eram simples; cada imagem visual estava ligada a sensações musculares, térmicas etc" ${ }^{22}$ No entanto, Funes estava aleijado, um cavalo lhe atirara ao chão, imobilizando-o para sempre. Paralítico, sua memória e percepção eram infalíveis. Está montada para Borges a equação entre excesso de memória e paralisia. Todavia, em que momento esse fluxo de a tudo transformar em repetição espetacularizada atinge a cultura ocidental? Nas três narrativas escritas por Milton Hatoum, Relato de um certo Oriente (1989), Dois irmãos (2000) e Cinzas do Norte (2005), a memória, seu excesso e destruição, é uma questão que se coloca. Os narradores desses relatos tomam a palavra com base em um espaço que, situado nem dentro nem fora do núcleo do enredo, os coloca na zona do impasse, da fronteira com o Outro, ou ainda, o espaço dos confins. Para o filósofo italiano Massimo Cacciari, "confim" é um espaço onde se instaura uma operação de guerra: lutar, conquistar, dividir e ordenar. E é daí que se cria a grande contradição que é a de se colocar diante do Outro e sua grande identidade e de sua memória vital. O confim, além de ser um limite que nos separa do outro, é o que nos colocaria cara a cara com ele porque envolve a noção de fronteira, uma vez que quem está na fronteira está próximo, e ainda lado a lado. ${ }^{23}$ Ao rememorarem

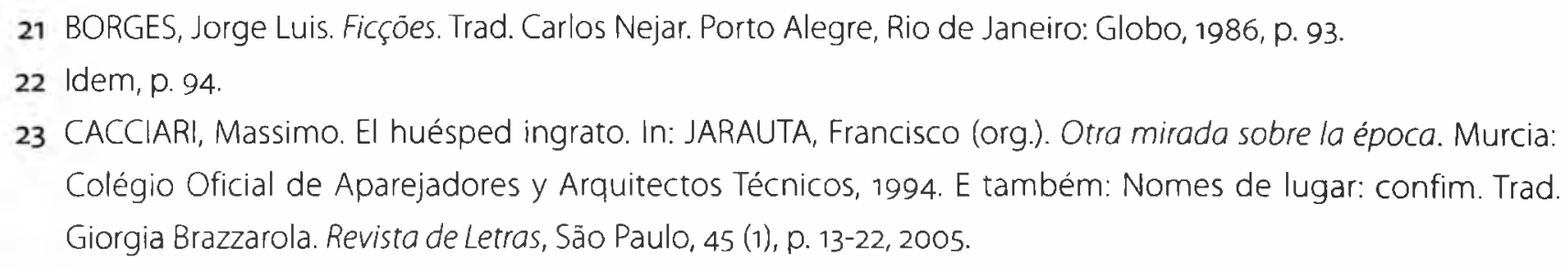


e tentarem reconstruir a história das famílias às quais não pertencem, os narradores dos três romances de Milton Hatoum não fazem senão destruir a integridade dessas histórias. Um tipo de vingança dos narradores contra o grande Outro que no fundo lhes é tão familiar? Ação contra si mesmo, contra a imposição da narrativa perfeita, mas inócua, que tanto perseguem esses narradores? Talvez seja esse o impasse que nos oferece a modernidade. Recordemos Macunaíma e o autômato de "História com data".

Foram os vanguardistas os nossos primeiros modernos porque perceberam esse impasse?

Coube a um vanguardista como Augusto de Campos no livro $\grave{A}$ margem da margem, publicado em 1989, oferecer uma leitura, que fazia falta, de um dos trabalhos sobre os quais se fundou a literatura moderna. Em "O Flaubert que faz falta", o poeta da extinta vanguarda concretista relembra que foi o próprio Borges, no artigo "Reivindicação de Bouvard e Pécuchet", publicado no jornal La Nación em 1954, aquele a ressaltar a atitude de rompimento de Flaubert para com o romance realista. $O$ efeito desse rompimento foi conduzir a sua obra para o futuro da literatura que, ainda segundo Borges, estaria sintetizado na relação que Mallarmé antevia entre o propósito do mundo e o projeto do livro, bem como no propósito da "língua infinita" que teceu o Ulysses. Para além de toda a pretensão desse traço absoluto do destino da literatura, Otto Maria Carpeaux, em "A época da classe média", no volume vi da sua História da Literatura Universal, ressalta a inversão da função do romance operada por Flaubert que, em sua ânsia pela conquista da narrativa perfeita, acabou por destruir o romance, inventando uma nova força para essa escrita, que é o "romance poemático moderno". Carpeaux sublinha ainda que "Madame Bovary é o primeiro romance rigorosamente construído como um poema". ${ }^{24} \mathrm{~A}$ função do romance, que até então fora construído sobre o fundamento da rememoração, daí sua relação com a história e, desse modo, com a memória do mundo, era a de reconstruir a saga dos heróis individualizados e das suas coisas. Com Flaubert o romance deseja oferecer sentidos, o que, tradicionalmente, era tarefa da poesia. Interessante é observar que em Flaubert, portanto, antes mesmo da poesia simbolista, marco da poesia moderna, são oferecidos "sentidos" mediante o uso de palavras e de coisas, isto é, da recordação que as coisas e as palavras criam através das alusões.

24 CARPEAUX, Otto Maria. A época da classe média. História da Literatura Universal. Rio de Janeiro: Editorial Alhambra, 1987, p. 1.454. v. VI. 


\section{Nietzsche e o poder de esquecer}

Diante de toda essa gama de contorções do discurso literário, que são também as contorções da vida humana, poderíamos dizer que na literatura moderna reside uma questão inexorável a todos que com ela se contorcem: a da capacidade daquele que escreve de se sentir partícipe de seu próprio ponto de vista, isto é, a capacidade de agir contra si mesmo, capacidade de se esquecer de si. Nietzsche, em 1874, na segunda de suas Considerações extemporâneas, "Da utilidade e desvantagem da história para a vida", fala de uma nova felicidade construída sobre a capacidade de "poder esquecer", e complementa:

[...] é possível viver quase sem lembrança, e mesmo viver feliz, como mostra o animal; mas é inteiramente impossivel, sem esquecimento, simplesmente viver. Ou para explicar-me ainda mais simplesmente sobre o meu tema: há um grau de insônia, de ruminação, de sentido histórico, no qual o vivente chega a sofrer dano e por fim se arruína, seja ele um homem ou um povo ou uma civilização. [...] o histórico e o a-histórico são igualmente necessários para a saúde dos indivíduos, dos povos e das culturas. ${ }^{25}$

O filósofo alemão faz uma distinção crucial entre os que ele chama de homens de cultura, aqueles burgueses da modernização industrial da Alemanha do final do século XIX, paralisados com o seu saber conquistado graças à prosperidade econômica que os torna incapazes de esquecer, pois estão presos ao seu passado e obcecados por acumular, e aqueles que atuam de uma maneira intempestiva, isto é, contra o tempo e, portanto, sobre o tempo e a favor de um tempo vindouro. A posição anticlerical de Nietzsche ainda é muito produtiva para a análise da nossa modernidade. Giorgio Agamben observa a relação entre a concepção de tempo histórico progressista do capitalismo e o rito cristão na sua indisposição em esquecer e devolver potência ao que está petrificado pelo rito. Posicionar-se contra o tempo acumulativo cristão-capitalista dos homens da cultura e da ciência para Nietzsche seria um antídoto ao utilitarismo em arte e à concepção finalista de mundo, mundo esse que deveria ser pensado sem messianismo e sem pragmatismo. Isso resulta numa posição de se estar "com" e "contra" a história, "com" e "contra" a memória do mundo.

25 NIETZSCHE, Friedrich Wilhelm. Considerações extemporâneas. Trad. Rubens Rodrigues Torres Filho. Sāo Paulo: Abril Cultural, 1983, p. 58. 
O sentir-se inseguro em um mundo sem verdades absolutas dos poetas simbolistas resultou num ocultismo, que em alguns poetas estará balizado pela disciplina formal parnasiana do l'art pour l'art. Essa insegurança é sintoma de uma fadiga intelectual, um atestado de falência do intelectualismo cientificista e do processo acelerado de industrialização e de acumulação do capital. Otto Maria Carpeaux assinalava em 1966 que "Nietzsche criou o simbolismo alemão". Com Nietzsche e com o simbolismo, um novo tipo de paganismo apresenta-se, um "gnosticismo" fruto da síntese de elementos gregos, cristãos e orientais. Baudelaire criaria sua própria seita "gnóstica" em cujo centro estava Lúcifer ${ }^{26} \mathrm{O}$ "gnosticismo", como seita pagã, seria mais apropriado ao pensamento por enigmas, isto é, ao pensamento alegórico de Baudelaire, do que o cristianismo em sua pureza e afirmação de identidade. $O$ anacronismo que disso deriva pode ser percebido naquelas concepções de tradição literária herdeiras do pensamento neopagão e extemporâneo dos simbolistas, como é o caso da concepção de tradição de T.S. Eliot. Nesse sentido sinalizou ainda Otto Maria Carpeaux:

Como americano, estrangeiro dentro da civilização europeia, não conhece fronteiras nacionais, mobiliza Ésquilo e Virgílio, Dante e Baudelaire, todas as literaturas de todos os tempos e países contra o "Waste Land" que lhe deve o apelido, criando um modernismo "sui generis", o modernismo reacionário. ${ }^{27}$

Se foi reacionário ou não, como o julga Carpeaux, caberia, então, hoje, a nós refletirmos sobre essa reação de Eliot? Reação contra que? Para o poeta norte-americano o fim da democracia moderna do século xix e o fim do romantismo foram os responsáveis pela catástrofe na qual estava imersa a cultura europeia do primeiro pós-guerra. Daí seu modernismo passar pela redescoberta da obra de John Donne, poeta barroco

O filósofo italiano Mario Perniola, ao analisar a cultura e a arte do nosso tempo, vem remarcando o diagnóstico de que há um retorno do paganismo e do politeísmo e que essa volta não está ligada ao nilismo, da mesma forma que nāo está relacionada a um modo esteticista de nos relacionarmos com a cultura. Perniola recorre ao livro de Marc Auge para reafirmar o caráter de não sublimação e não relacionamento ou de qualquer intimidade entre homem e divindade do paganismo. A possessão pagã não tem nada a ver com comunhāo, os deuses são potências e não pessoas. O culto pagão é uma prática rigorosamente impessoal. Cf. PERNIOLA, Mario. Enigmas, egipcio, barroco, neo-barroco en la sociedad y el arte. Trad. Javier Melenchón. Murcia: CedeaC. 2006. Nesse sentido, pode-se compreender também como o paganismo ou o gnosticismo dos simbolistas está de acordo com a despersonalização da poesia empreendida por aqueles artistas.

27 CARPEAUX, Otto Maria. Literatura e realidade. História da Literatura Universal. Rio de Janeiro: Ediçōes. O Cruzeiro, 1966, p. 3.215. v. VII. 
que criou, no poema "A relíquia", um extraordinário espaço intermediário entre a coisa, a palavra e o homem, com a montagem "túmulo-mulher-pedra", ${ }^{28}$ e de Gerard Manley Hopkins, poeta neorromântico e padre jesuíta do século XIx. E muito ainda há que se dizer do pessimismo e do esteticismo de Eliot, os quais atestam suas relações textuais e de pensamento com o simbolismo francês, não no que se refere ao anticlericalismo, mas na negação da modernidade capitalista e liberal e na sua admiração pelos autores dos séculos xvir e xviII. Sabemos, mediante o estudo de Walter Benjamin, que Baudelaire era um admirador dos jesuítas. ${ }^{29} \mathrm{Em}$ meu ensaio " $\mathrm{O}$ jardim imemorial As flores do mal e as formas primordiais da arte", ${ }^{30}$ tentei demonstrar o quanto essa admiração pelos jesuítas da parte de Baudelaire, como posteriormente da parte de Benjamin, relaciona-se à leitura de ambos da obra de Baltasar Gracián, em especial no que se refere a uma estética da ausência, da falta, do caráter "inexperimentável" e, portanto, não acumulável nem transferível, do saber decorrente do discurso poético. Em Agudeza y arte de ingenio, o padre jesuíta recomenda:

[...] quien dice misterio, dice preñez, [...]. Las contingencias son la ordinaria materia de los misterios [...]. Fúndase el misterio tanto en lo positivo como en lo negativo de las circunstancias, y hácese el reparo, así en la que concurre como en la que faltó, si bien es menester más fundamento cuando se forma por carencia. ${ }^{31}$

Nesse sentido, os jesuítas reaparecem no pensamento sobre a modernidade como antimodernos que foram, inclusive quando permitiram um cristianismo sincrético nas missões da China e do Brasil, aproximando-o tanto do confucionismo como da religiosidade dos índios da América Latina. Talvez Nietzsche pudesse ver os jesuítas com esse novo olhar e, desse modo, os deixasse livres do seu julgamento de criarem a noção de fim, de fenecimento da humanidade que enfraquece porque nada há mais para se realizar já que o fim do mundo e o tempo da redenção estariam próximos. Há que se sublinhar que a expressão discursiva, portanto vital, de Baltasar Gracián é a "carencia”, a expressão que se faz por ausência. Esse é o

28 Augusto de Campos em sua tradução do poema "A relíquia" chama a atenção para essa montagem "túmulo-mulher". Cf. O anticrítico. São Paulo: Companhia das Letras, 1986.

29 Cf. BENJAMIN, Walter. Paris do segundo império. Charles Baudelaire: um lírico no auge do capitalismo. São Paulo: Brasiliense, 1994.

30 Cf. SCRAMIM, Susana. O jardim imemorial: As flores do mal e as formas primordiais da arte. Alea, Revista do Departamento de Estudos Neolatinos, Rio de Janeiro: UFRJ, v. 9, 2008.

31 GRACIÁN, Baltasar. Agudeza y arte de ingenio. Madri: Editorial Castalia, p. 89, 2001.

230. SCRAMIM, Susana. O livro-mundo. Milton Hatoum e a literatura do presente 
reconhecimento de uma negatividade do saber decorrente da poesia por parte desses mesmos jesuítas. De um saber não consciente, não cumulativo, não comunicável, portanto, intransferível por meio de heranças e espólios.

Romper a paralisia decorrente do recebimento da herança é tarefa nossa, "roubar o silêncio", para utilizar aqui o título do último livro de poemas de Marcos $\operatorname{Siscar}^{32}$ e, dessa maneira, acertar nossas contas com a modernidade, adquirir capacidade de "esquecer" para, então, poder lembrar.

\section{Esquecer para lembrar}

Já referimos no início deste estudo que, em Il ricordo del presente: saggio sul tempo storico e em "A potência do pensamento", Paolo Virno e Giorgio Agamben nos relembram de que "dynamis" para Aristóteles é potência que permite lembrar porque deriva de uma privação, de uma falta; desse modo, poderíamos pensar a "dynamis" como a força que permite lembrar. No entanto, essa força não é a de transformar a recordação em realidade, não é a força de fazer inventários.

Os narradores dos romances de Milton Hatoum assumem a tarefa de fazer os inventários da memória do seu mundo particular. Contudo, seja decorrente de uma personalidade esquizóide, no caso da narradora que ficou reclusa em uma clínica psiquiátrica durante anos, em Relato de um certo Oriente; seja por tentar responder para si mesmo sobre a verdadeira identidade de seu pai, no caso de Nael, o professor de literatura e filho bastardo de um dos irmãos da família na qual sua mãe trabalhava como empregada, em Dois irmãos; ou seja por dever de ofício do advogado Lavo em reconstruir os fatos para tentar compreender como se chegou à degradação da cidade, mas também, por amor ao amigo Mundo, tentar compreender como essa degradação fez parte de sua vida, em Cinzas do Norte; esses narradores percorrem o caminho inverso ao do relato realista ou naturalista da prosa cujo objetivo é o de verificar e reviver os fatos. Participando do destino de Flaubert, ${ }^{33}$ o relato de Hatoum

32 Cf. SISCAR, Marcos. O roubo do silêncio. Rio de Janeiro: 7 Letras, 2006.

33 Samuel Titan Jr. já sublinhou a herança de Flaubert no trabalho de Milton Hatoum. Titan desenha o arco que vai desde o"Un coeur simple", com a história da velha criada e a lembrança do sobrinho viajando por mares longínquos cuja única lembrança se materializa num papagaio, passa pelo papagaio "Laure"em Relato de um certo Oriente, pela empregada doméstica "Domingas" de Dois irmãos e o desejo de escrever a história moral de sua geração em Cinzas do Norte. Esse desenho apresenta o engano geral da humanidade, um engano acerca da verdadeira natureza das coisas. Engano e estupidez humanos estão nessas obras correlacionados. 
se enfrenta com seu próprio destino: o rompimento com o idealismo que constitui o princípio ativo da construção das obras desses autores. O idealismo, herança do romantismo, nos dois trabalhos, é o estilo. Há uma busca obsessiva pela palavra certeira e a frase justa, que não é propriamente l'art pour l'art. Esse idealismo estilístico não se materializa somente como "objetivização" da forma, mas antes por uma opção pelos temas humanos que serão vistos e trabalhados pela mão de um ser de exceção, um narrador incluído naquilo que poderíamos pensar como uma "cultura humanista". Os narradores dos romances de Milton Hatoum são seres de exceção. A narradora principal do Relato de um certo Oriente é uma moça que passa anos em tratamento psicológico. Nael, de Dois irmãos, é um professor de literatura do Liceu Rui Barbosa. O narrador de Cinzas do Norte é o advogado Lavo. Tomando os narradores como seres de exceção, a literatura se enfrenta com suas questões mais próprias que não deixam de gerar os mesmos impasses. Como sair da constatação de que tudo ao seu redor é um oceano de imbecilidades as quais somente o narrador é capaz de reconhecer? Como sair do impasse de que somente ele, o narrador, é capaz de apresentar a estupidez humana com força de verdade pela ironia objetiva de sua arte estilística? Questões como essas habitam o presente da literatura: como sair do impasse da função analítica do desmascaramento e da função ativa, não no sentido de "dynamis", mas no de ato propriamente dito, de toda a "education"? Essa não é uma questão restrita à modernidade literária, digamos que ela pertence ao âmbito do trabalho artístico e, portanto, é extemporânea. Contudo, transpondo essa discussão para a arte moderna, surge a questão: como sair dos impasses enfrentados e muitas vezes criados pelas vanguardas, sejam elas formalistas ou socialistas?

Algumas obras já discutiram e questionaram tais problemas. Mesmo anacronicamente, ainda é interessante lembrar aquele "destino" da obra de Flaubert, evocado por Borges, retomado por Augusto de Campos, de que o escritor francês já não queria escrever mais romances..$^{34} \mathrm{O}$ destino do romance de Flaubert era o livro-mundo

A vingança moral que Flaubert quer aplicar à estupidez humana se assemelha ao desejo de Milton Hatoum de escrever a história moral de sua geração; entretanto, acabam ambos por enfrentar os mesmos impasses.

34 Borges, já aos 23 anos, sinaliza sua preferência pela expressão literária na qual o "eu" esteja suprimido e a forma artística vinculada à força informe da arte. No primeiro número da revista mural Prisma, publicada em Buenos Aires, em 1922، Borges critica aquele que faz "um soneto para colocar uma linha e dizer em duzentas páginas o que caberia dizer em duas linhas. (Desde já se pode assegurar que o romance, essa coisa maciça arquitetada pela superstiçāo do eu, vai desaparecer, como sucedeu com a epopeia e com outras categorias dilatadas.)" Cf. SCHWARTZ, Jorge. Polêmicas, manifestos e textos críticos. Vanguardas latino-americanas. Sāo Paulo: Edusp, lluminuras, Fapesp, 1995, p. 113.

232. SCRAMIM, Susana. O livro-mundo. Milton Hatoum e a literatura do presente 
de Mallarmé e o livro da língua infinita do Ulysses. Escrever um romance-poema era a meta da modernidade anacrônica de Flaubert, o que não quer dizer escrever um poema formalista, e sim escrever um romance em que a habilidade de produzir relatos cedesse lugar ao poder de produzir ausências, produzir esquecimentos. Essa se constituiria, talvez, na marca indelével do presente na literatura. ${ }^{35}$

Em Relato de um certo Oriente, quando a narradora reencontra em Manaus o fotógrafo Dorner numa praça à beira-rio, a cena que descreve esse encontro opera uma combinação sinfônica entre o burburinho produzido pelo movimento da cidade na selva, os sons da tempestade que golpeava o teto da igreja na qual eles se abrigaram do temporal e o diálogo entre a narradora e o fotógrafo alemão. O barulho da chuva alterava o volume da voz de Dorner que contava à moça alguns fatos de sua longa permanência em Manaus. Para esquivar-se de falar sobre sua própria vida, a narradora apressava-se em perguntar sobre a vida dos amigos, vizinhos e conhecidos da cidade, isto é, sobre a vida imbecil da província. No entanto, eles não conseguiram por muito tempo manter o ritmo tolo dessa conversação, um tipo de composição polifônica que, além de revelar a ironia amarga do texto, se apresenta como insustentável. A força do romance-poema logo irromperia e o que fora esquecido retorna e oferece os sentidos que a prosa do romance não alcança. E mais uma composição é orquestrada. Ao mesmo tempo em que a narradora deseja desvencilhar-se de Dorner, outra temporalidade corre ao lado, a das aulas de música do passado, lá onde toca a sonata A menina e a morte, de Schubert. À imbecilidade da vida na província se superpõe uma abertura para o acontecimento dos sentidos do relato cujo efeito não será manifesto nesse momento e em nenhum outro momento do texto. Eles, os sentidos, serão construídos fora do relato, num outro lugar, ou seja, no lugar da ausência do sentido do romance e da vida, o que não deixa de ser a existência mesma da própria poesia. A propósito, é interessante ainda assinalar outro fluxo paralelo, a composição também de uma polifonia ausente, que são os poemas ausentes de Antenor Laval em Dois irmãos. Os versos que, estando ali presentes na composição do texto, nunca aparecem - apenas a pasta preta de Laval é encontrada depois por Nael - e isso não anula a força da música ausente de seus versos que se apresentam, dessa forma, como nota principal da partitura. O acontecimento poético novamente

35 Sobre o conceito de presente e de literatura do presente desenvolvi um estudo fundamentado no conceito de ruina e história cultural petrificada de Walter Benjamin, bem como no conceito de "aporia" de Giorgio Agamben. Esse estudo se materializou no meu livro Literatura do presente: história e anacronismo dos textos. Chapecó: Universitária Argos, 2007.

Teresa revista de Literatura Brasileira [10|11]; São Paulo, p. 216-235, 2010. - 233 
é uma sinfonia silenciosa, recordações, relíquias de uma poesia desaparecida, silenciada, mas presente. A relíquia, nesse caso, são os versos de Rimbaud, poeta que silenciou a poesia, e de Baudelaire, poeta da paradoxal revolta contra a modernidade burguesa. Os versos de Rimbaud não estão ali, mas se ouvem:

\section{$[\ldots]$}

J'ai rêvé la nuit verte aux neiges éblouies,

Baiser montant aux yeux des mers avec lenteurs,

La circulation des sèves inouies,

Et léveil jaune et bleu des phosphores chanteurs ! [...] $]^{36}$

É Laval quem recita os versos para os alunos durante as aulas de língua francesa, mas a voz do poema está ausente, sua presença é apenas uma recordação do narrador, uma relíquia. "Não ensinava a gramática, apenas recitava, barítono, as iluminações e as verdes neves do seu adorado simbolista francês. Quem entendia essas imagens fulgurantes?" ${ }^{37}$ Tampouco a voz dos poemas de Baudelaire está ali, mas há a força da ausência a oferecer potência ao poema, ao romance e ao romance-poema. Na aula que antecedeu a sua prisão política pelo regime militar, Laval escreveu com mão trêmula de pavor os versos de um poema dos quais o narrador só compreendeu um: "Je dis: Que cherchent-ils au ciel, toutes ces aveugles? O resto era ilegível, ele se esquecera do título, e por um momento nos lançou um olhar estranho" ${ }^{38} \mathrm{O}$ poema ficou ilegivel para o narrador, mas não era preciso ter olhos para ver, os cegos são os personagens principais do romance.

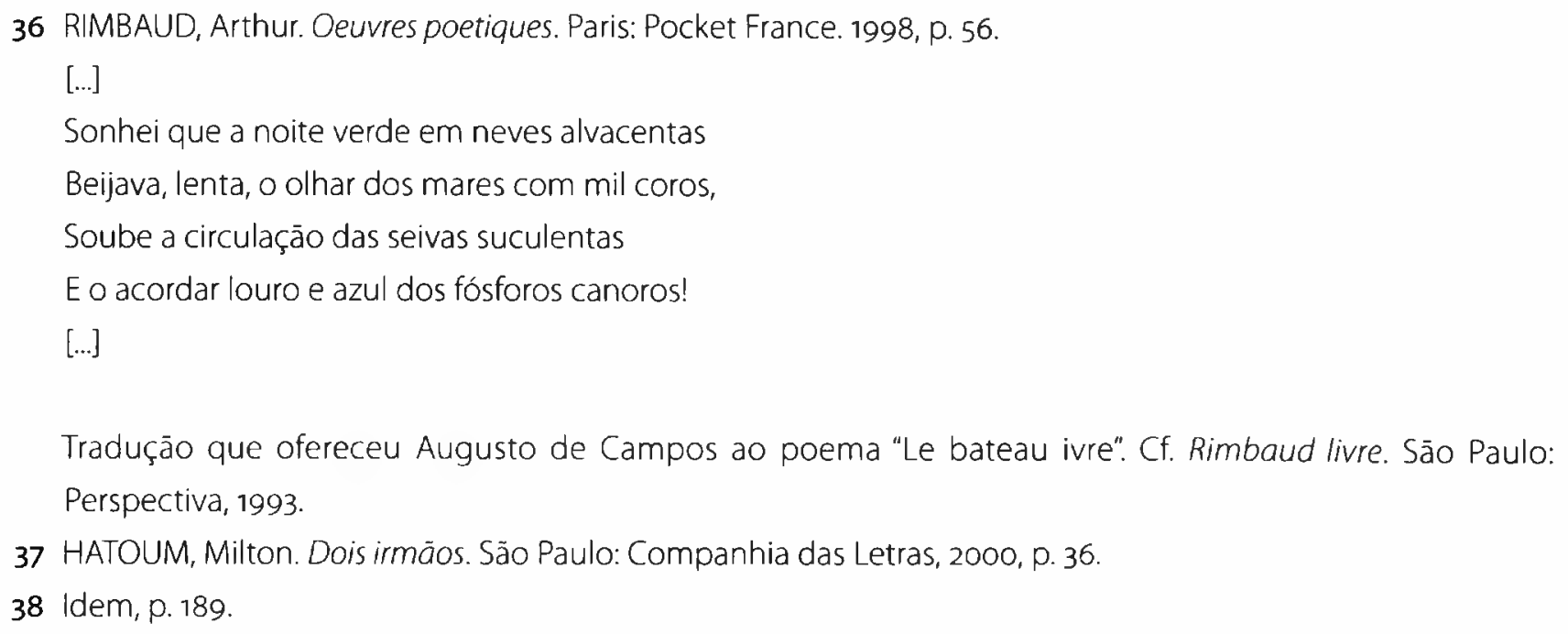




\section{$[\ldots]$}

Ils traversent ainsi le noir illimité,

Ce frère du silence éternel. O cité!

Pendant qu'autour de nous chantes, ris et beugles,

Éprise du plaisir jusquả l'atrocité,

Vois! je me traîne aussi! mais, plus queux hébété,

Je dis: Que cherchent-ils au Ciel, toutes ces aveugles?39

Não estar visível não quer dizer que ele, o poema, não esteja ali, a latejar, a tocar a sua música ausente. Não há necessidade de olhos para ver nem direcionar esses mesmos olhos para o céu, o que importa para o romance-poema é cruzar o "silêncio infinito" Em Relato de um certo Oriente, os olhos que veem mais do que a mera realidade também são personagens que produzem ausências. A narradora apresenta-nos o procedimento pelo qual compôs a sua sinfonia: "Para te revelar [...] que Emilie se foi para sempre, comecei a imaginar com os olhos da memória as passagens da infância, as cantigas [...]" ${ }^{40}$ Há um poema, que permanece inédito, intitulado justamente "Os olhos da memória", que Milton Hatoum compôs paralelamente à escrita do Relato.... É o poema da morte e a menina. Outra sinfonia ausente. E se igualmente refletimos sobre a arte que o personagem Mundo quer produzir no livro Cinzas do Norte, veremos que, mais do que produzir um fazer artístico, a arte de Mundo cria um "desejo de ser arte", visto que sua arte nunca se completou, nunca se apresentou como acabada e perfeita. Nesse sentido, outra sinfonia pode ser ouvida nesse silêncio: a da literatura do presente.

$39[. .$.

Cruzam assim o eterno escuro que os invade,

Esse irmāo do silêncio infinito. Ó cidade!

Enquanto em torno cantas, ris e uivas ao léu,

Nos braços de um prazer que tangencia o espasmo,

Olha! também me arrasto! e, mais do que eles pasmo,

Digo: que buscam estes cegos ver no Céu?

Tradução que ofereceu ao poema "Les aveugles", de Baudelaire, o poeta Ivan Junqueira. Cf. BAUDELAIRE, Charles. As flores do mal. Tradução e notas de Ivan Junqueira. Rio de Janeiro: Nova Fronteira, 1985. p. 342. 40 HATOUM, Milton. Relato de um certo Oriente. São Paulo: Companhia das Letras, 1989, p. 166. 


\section{Literatura do presente}

Walter Benjamin escreveu o seu trabalho sobre o drama barroco alemão motivado por esse conceito do presente, isto é, um presente artístico-filosófico. O que Benjamin buscava eram "as formas primordiais" da arte, intimamente ligadas ao próprio conceito de origem desenvolvido nesse mesmo trabalho. Encontrou as "formas originárias" do drama barroco alemão no século XVII e xVIII e detectou como elas sobreviviam nas "formas originárias" do expressionismo alemão da primeira década do século xx. Além de formular uma teoria das "formas primordiais" na arte, baseado na leitura de Goethe sobre as "formas originárias", Walter Benjamin produz um conceito de tempo, ou melhor, de tempo presente na arte. O tempo presente se constitui com base no conceito de "forma originária".

Desse modo, as obras do tempo presente, além de manifestarem uma forte opção pela arte produtora de pensamento, estariam ligadas a certas noções de fazer literário que incluem um "não fazer" e reafirmam, ao contrário, apenas um "querer" fazer, isto é, incluem uma noção de abandono do próprio ato de "fazer" literatura. Walter Benjamin detecta essa modulação de arte do presente no barroco do século xviII e no expressionismo. Partindo desse método, que deve ser entendido como um procedimento crítico, essa comunidade do presente pode ser aumentada mediante uma modulação desses mesmos procedimentos na arte. Assim, uma tentativa de fazer conjunto crítico dessas obras, abrigando-as em uma nova tendência ou grupo, estará sempre marcada por sua mais fiel característica: a de ser incompleta ou de ser provisória, uma vez que obras serão justamente analisadas com base em um "querer ser" e não efetivamente em um "ser" arte. É daqui que surge a posição política de algumas obras do presente de abdicarem definitivamente da característica de "ser arte". Esse "abandono" pode levar a uma ultrapassagem dos limites de mediação entre a realidade e a ficção, limites entre os quais a arte modernista se situa, assumindo-se como uma prática fluida que promove o trânsito entre as fronteiras dos gêneros da crítica e da ficção ou ainda levando à enunciação de uma forte negatividade ativa. Nesse sentido, a arte do presente, ou ainda, a literatura do presente é ficção no mesmo momento em que é ensaio ou crítica, no entanto, sendo ao mesmo tempo todas essas modalidades discursivas, não é nenhuma delas autonomamente.

Caberia ainda lembrar, para terminar esta análise sobre o trabalho poético desenvolvido por Milton Hatoum, o que Augusto de Campos apontava como o Flaubert que faz falta, aquele do projeto de livro inacabado, de Bouvard e Pécuchet, o livro dos

236- SCRAMIM, Susana. O livro-mundo. Milton Hatoum e a literatura do presente 
dois copistas que tentam registrar a memória do mundo, "protofiguras" de Pierre Menard e de Funes. A arte que resulta desse empreendimento dos copistas é o livro-gênio cujo sentido, como bem lembra Augusto de Campos, Flaubert tenta mimetizar no verbete de seu Dicionário de ideias feitas. No dicionário de Flaubert, segundo a correspondência do escritor francês, seria a parte final do livro inacabado, Bouvard e Pécuchet, gênio pertenceria à categoria dos grandes temas da psicologia, pois que "Gênio - é inútil admirá-lo. Trata-se de uma nevrose".41 Um livro gênio, perfeito, que deveria ser a memória realista da humanidade, mas que se efetivou como memória artificiosa, produto da ação de um esnobe ${ }^{42}$ o qual, como ressalta Paolo Virno, relendo o comentário de Alexandre Kojève sobre o esgotamento da história diagnosticado por Hegel como o "domingo da história", "põe a nu os fundamentos dos conflitos históricos, já que se empenha em representar, mediante uma série de gestos determinados, o contraste que subsiste entre o gesto humano e o ser-dado".43

O livro-gênio, isto é, o romance-poema, foi produto da cópia, produto da pós-experiência, da pós-história, da pós-literatura, da pós-crítica e ainda de uma neurose. Voltaram os homens a catar, a copiar e a catalogar a falta de sentido das coisas.

Susana Célia Leandro Scramim é professora na Universidade Federal de Santa Catarina, pesquisadora do Núcleo de Estudos Literários e Culturais - NELIC/ UFSC. Escreveu Literatura do presente: história e anacronismo dos textos (Argos, 2007). Organizou as edições especiais da revista Outra travessia sobre Euclides da Cunha (UFSC), Giorgio Agamben e Georges Bataille (UFSC).

41 FLAUBERT, Gustav. Bouvarde Pécuchet. Trad. Galeão Coutinho e Augusto Meyer. Rio de Janeiro: Nova Fronteira, 1981, p. 299.

42 Giorgio Agamben, em uma das mais interessantes análises sobre a poesia, o seu estudo sobre o seminário de inverno de 1929-30 de Heidegger, Die Grundbegriffe der Metaphysik, isto é, sobre a privaçāo e o suplemento existente entre o homem e o animal, discute a categoria do esnobe em Kojève. Agamben cita como epígrafe ao fragmento intitulado "Snob" o próprio Kojève: "Nessun animale può essere snob". Cf. AGAMBEN, Giorgio. L'uomo e l'animale. L'aperto. Torino: Bollati Boringhiere, 2002.

43 VIRNO, Paolo. El recuerdo del presente. Ensayo sobre el tiempo histórico. Buenos Aires: Paidós, 2003, p. 45. 